1998

\title{
Reconstruction of the Part Vegetation on the Headwaters of the Piney Creek Watershed in Houston and Trinity Counties, Texas
}

Velicia R. Hubbard

Unknown

David H. Jurney

Follow this and additional works at: https://scholarworks.sfasu.edu/ita

Part of the American Material Culture Commons, Archaeological Anthropology Commons, Environmental Studies Commons, Other American Studies Commons, Other Arts and Humanities Commons, Other History of Art, Architecture, and Archaeology Commons, and the United States History Commons

Tell us how this article helped you.

This Article is brought to you for free and open access by the Center for Regional Heritage Research at SFA ScholarWorks. It has been accepted for inclusion in Index of Texas Archaeology: Open Access Gray Literature from the Lone Star State by an authorized editor of SFA ScholarWorks. For more information, please contact cdsscholarworks@sfasu.edu. 


\section{Reconstruction of the Part Vegetation on the Headwaters of the Piney Creek Watershed in Houston and Trinity Counties, Texas}

\section{Creative Commons License}

\section{(c) (1) \&}

This work is licensed under a Creative Commons Attribution-NonCommercial 4.0 International License 


\title{
RECONSTRUCTION OF THE PAST VEGETATION ON THE HEADWATERS OF THE PINEY CREEK WATERSHED IN HOUSTON AND TRINITY COUNTIES, TEXAS
}

\author{
Velicia R. Hubbard and David H. Jurney
}

\begin{abstract}
The National Forests and Grasslands of Texas began a project in 1994 for ecosystem management involving multiple disciplines in an holistic approach to resource inventories. We first began with an intensive archival study of the forest acquisition files and the General Land Office (GLO) files in an effort to identify the western limits of the longleaf pine at the time of initial Anglo-American settlement ca. 1850. Vegetation information was gleaned from this work along with an understanding of the historical occupation of the area, aided by plotting this information onto USGS 7.5' maps overlain by the historic Tobin landownership maps. We have since narrowed our focus from the mosaic of a broad area, to the headwaters of the Piney Creek watershed, an area rich in prehistory and history. Archeological survey has provided data for prehistoric occupations dating to the Early Ceramic period (ca. A.D. 500). More recent deed records, and subsequent landline surveys, have data on witness trees in the $1830 \mathrm{~s}$, $1860 \mathrm{~s}$, and $1890 \mathrm{~s}$, and then again after the Forest Service acquired the land in the $1930 \mathrm{~s}$, offering an opportunity to study specie composition over a 100 year period. This study on specie composition, tree density, and basal area, provides preliminary indications that fire suppression in the historic period significantly altered the forest composition.
\end{abstract}

\section{Introduction}

Ecosystem management is part of the Forest Service's answer to increased public demand for an integrated and holistic resource approach to the management of Federal lands (Forney 1993). Ecosystem can be defined as a biological community within its physical environment. Although Texas' National Forests comprise a relatively small part of a larger ecosystem, these forests can offer significant ecosystem management opportunities not present on many other lands. We are told that consistent monitoring is the key to ecosystem management, and if that is indeed the case, then we must first look at what historical data can offer, and catch up to the present day, so to speak, so that we may begin to do a more efficient job in managing all our resources.

An historical viewpoint provides a better understanding of ecosystems, people, and natural resource relationships. Presettlement areas may have consisted of systems that were relatively ancient and stable (Noss 1985). If this is the case, once these areas are researched and mapped, they should provide a sound basis from which to measure what humans have altered. As we all know, when humans colonize an area in large numbers, they replace natural processes with a whole new set of disturbances.

Functional ecology is now being emphasized rather than the deseriptive ecology of the past. However, if there had not been a descriptive ecology, we would not be able to consider the functionality of ecology today. Archeologists with the National Forests and Grasslands of Texas began to peruse the land archives in January 1994 for the vegetation and cultural resources data they contain. Critical evaluation of the historical data provided information on the presettlement conditions of the area, and this data can then be compared to present- 
day conditions. The human dimension should also be considered when evaluating past and present ecological conditions. In concert with the archival research, edaphic factors were also important to consider, as we hope to demonstrate a strong relationship among the forest types, drainage profiles, soil texture classes, soil types, and geology. Many potential sources have been consulted, searching for corroboration, and permitting the integration of qualitative information into the project.

The project has been refined since 1994, and we are focusing on a smaller area (the upper reaches of the Piney Creek watershed), rather than attempting to analyze the mosaic pattern of broad spatial areas. Presented herein is the data we have accumulated from archaeological reconnaissance, the evaluation of the historical data, and a look at the present-day vegetation.

\section{Natural Environment in the Study Area}

Topographically, the area under consideration is gently rolling with slight relief. It is a well-watered temperate woodlands with prairie patches, and the bottomlands are broad to nearly level. Piney Creek drains into the Neches River. 'The creek meanders, and its tributaries have a dendritic pattern with no apparent structural control. The only gradational agent in this humid zone is running water aided by local gravity movements (e.g., Butzer 1964). The Carrizo-Wilcox fresh water aquifer underlies the study area.

The Piney Creek area is part of the Gulf Coastal Plain with marine and terrestrial sediments dating to the Cenozoic era. The structure is known as the Cenozoic Gulf Geosyncline, and includes the Catahoula, Fleming, and a portion of the Willis formations (Bridges 1989). The structure of the West Gulf Coastal Plain is a result of transgressing and regressing marine water that left a strata of coarse fluvial sediments and a strata of a finer-textured marine sediment. The finer stratum consists of fine-grained sands, clays, shales, and marl. At times, the underlying materials will outcrop and expose their gulfward-dipping trend. The sand content is high due to the translocation of clay materials to greater depths.

The climate in this area is humid in the summers, the winters are mild (snow is rare), and the rainfall averages $44-48$ inches a year. This is an ideal climate for forest growth and for a variety of animals.

\section{Prehistoric East Texas}

At the beginning of this project, two archaeological sites had been previously recorded in the Piney Creek watershed. The land between the Red and Trinity rivers is traditionally known as the "land of the Tejas" or the land of "friends." This area has been occupied by the prehistoric Caddo people and their ancestors for thousands of years. The George C. Davis site (Caddoan Mounds State Historic Park) was a sacred area and ceremonial center of the Caddo people from as early as A.D. 800. This mound complex is situated in Cherokee County, northwest of the study area. There, and in the Piney Creek area, Native Americans created a new landscape and a new ecology. They replaced the existing landscape and wildlife with a humanized one that was sustainable over a long period of time. They used and managed the natural resources for their survival; there is no doubt that these efforts significantly altered ecosystems in the vicinity of settlements (Flanagan 1992). To what extent the ecosystems at large were affected, and whether these alterations were for the better are questions we may never answer with certainty. Nevertheless, we know that the Caddo people living at and around such centers as Caddoan Mounds survived in a 
remarkably stable relationship with their environment for hundreds of years prior to the introduction of European diseases and their influences.

Prairies and savannas may be a product of Native American lifeways that ended with White settlement. Their use of fire led to the creation of park-like areas facilitating hunting, cultivation, and the collection of natural resources. Fire also reduced vermin and poisonous plants. Controlled, or sporadic, fires also reduced the amount of wood debris that had built up. This undoubtedly would have reduced the risk of catastrophic fires and helped to maintain the wildlife (Peterson 1994). Until Native American impacts are fully understood and discussed, there is little likelihood that today's forest managers can mimic, restore, or maintain pre-settlement forest conditions that may have been largely a result of the aboriginal use of fire.

An archaeological reconnaissance of part of the Piney Creek watershed was conducted to provide data on the prehistoric past. Research of the files at the Davy Crockett National Forest indicated that additional prehistoric sites in the piney Creek watershed had been discovered since 1992, and these sites were revisited and recorded. The two previously recorded sites, and the 10 sites we have recorded, have helped us to begin understanding the story of this watershed. Six of the sites are prehistoric, one is historic age, and the remaining five have both prehistoric and historic components. Most of the prehistoric sites yielded diagnostic artifacts that date from 2500 B.C. to A.D. 1500 . The historic components appear to be logging camps. At one site there is a tram, or logging railroad; this site also has a prehistoric component. When the tram builders were building the tram, they quarried the soil from the prehistoric site. Another prehistoric and historic site had historic ceramics that date from the $1890 \mathrm{~s}-1910$. Finally, Camp Pennington, a short-term Civilian Conservation Camp, was established in the 1930s in the Piney Creek watershed. With these dates in mind, it is easier to visualize the continuous occupation of the Piney Creek watershed over the last several millennia.

\section{Historic East Texas}

Land acquisition files from the Forest Service archives in Lufkin, Texas, and the General Land Office (GLO) in Austin, have been researched to obtain land survey data for the watershed. Some of these surveys date from as early as the $1830 \mathrm{~s}$ when the land was under Mexican control, to the 1920s when the Forest Service acquired the land. Other records document subdivisions of the lands, and also include affidavits, petitions, and other legal proceedings. While the field notes of surveys provide corner (bearing) trees, other documents in the land records include valuable information pertaining to the land and the environment. It is these documents that the archaeologist covets because they can, at times, reveal tidbits of valuable historical information.

A brief history of Texas allows us to envision how it differs from other southern states in land survey methods. Texas's Spanish heritage resulted in land being surveyed in haphazard accumulations of irregular metes and bounds using the Spanish measuring system of the vara (33.33 inches) rather than the orderly grid of the range and township system used in the rest of the United States. The land grants varied in many ways other than just shape and area. The surveyors had instructions that rivers, large streams, and lakes were to be considered as natural boundaries, and that no survey was to cross these features. The problem of individual surveyor bias is often mentioned as a cautionary note, and few reconstructions based on these kinds of land surveys present intensive analysis of the individuals or the local historical circumstances. The distribution of tree diameter classes can be used to detect individual or group bias towards certain sizes or species (Jurney 1987). 
The various dimensions of land divisions in Texas after 1836 were based on a number of factors (Jumey 1987, 1988a, 1988b). Land grants were initially established to reward veterans who had fought for independence from Mexico. Headright's and bounties were granted from 1836-1842 in tracts of 1280 acres, 640 acres, or 320 acres, depending on the claim and the claimant's marital status. Homestead exemptions were also granted to those who had previously occupied and had demonstrated improvements to the land; the tract could not exceed 320 acres in size. Later homestead exemptions were granted for 160 acres, but the preemptor was required to live on the land for three years and show improvements before the land was granted. Bounty warrants were additional donations or awards to veterans, and included those who fought at the Battle of San Jacinto, the Alamo, and the War of Texas Independence. There were also Railroad grants and land set aside for county schools.

The Municipality of Nacogdoches was created in the early $1800 \mathrm{~s}$, and then later subdivided. Houston County was created from the Nacogdoches Municipality, and it included the northern part of what came to be Polk County, all of Trinity, Houston, and Anderson counties, and the southern part of Henderson County. Trinity County was created in 1841, and Sumpter was the county seat in 1854. The courthouse and jail were built that year with pine logs harvested from the surrounding forest. Also in Trinity County, J. T. Evans bought a plantation on Piney Creek to raise slaves for market (Bowles 1966). This plantation was surrounded by stately pines and black jack oak saplings. In Houston County in 1890, coal was discovered on James Baker's land. He was living on Piney Creek and was digging a well when he found a vein of coal six inches thick (Urlich 1984).

The 1880 census stated that the population in Trinity County was 4914 . This included 3753 whites and 1164 coloreds. The county encompassed 710 square miles, and 23,491 acres were tilled. Houston County's population that same year was 16,702, with 9465 whites and 7237 coloreds. The county covered 1170 square miles, and 73,884 acres were tilled (Loughridge 1884).

\section{Landscape, Past and Present}

The land research on the Davy Crockett National Forest has compiled data relating to three historical periods. The first is the original surveys of the public domain, with surveys dating from 1826-1876. The second, dating from 1868-1912, is subdivisional surveys in which these large land grants are cut into smaller parcels and sold by private citizens. The last period consists of 1930 tract inventories belonging to private timber companies, and U.S. Forest Service surveys dating from 1935-1938. Although these three data sets are variable in their coverage of the landscape, they provide a 112 year sample of the forest composition in the form of witness trees.

Through time, the land grants offered by the Mexican, Republic of 'Texas, and State of Texas governments were reduced in area to accommodate increasing numbers if settlers. The Mexican period is represented by 22 land grants, averaging 4315.17 acres in size. The Republic of Texas period has four land grants averaging 3515 acres, and the State of Texas period land grants $(n=18)$ average 351.983 acres. The Civil War was marked by the sale of lands for building railroads and funding the Confederate war effort, with nine land grants averaging 366.888 acres. The Reconstruction (1866-1876) effort land grants $(n=6)$ average 266.667 acres. 
The land was primarily distributed during the Mexican period (37.3 percent of the tracts and 79 percent of the acreage $[94,933.716$ acres $])$ and the Republic of Texas period (6.8 percent of the tracts and 11.7 percent of the acreage [14,060 acres]). Prior to the Civil War (1851-1859), the State of Texas actually witnessed the second most frequent period of grants ( 30 percent of the tracts), but the total area of these (5.3 percent of the acreage and 6335.7 acres) reflected the diminishing vacant lands. During the Civil War, the number of tracts granted ( 15.3 percent) diminished along with the acreage ( 2.7 percent of the acreage and 3302 acres). The last of the vacant land was claimed during Reconstruction, with 10.2 percent of the tracts and 1.3 percent ( 1600 acres) of the acreage.

The original land grants were subdivided as settlement increased. Transportation facilities improved to allow the commercial exploitation of the forest. The studied sample consists of 35 tracts dating from 1868-1912. Subdivisions of the original grants began even before all vacant lands were claimed, although relatively few subdivisions were conducted between 1868-1877, with only 5.7 percent of the tracts and 2.6 percent ( 309.5 acres in the studied sample) of the total acreage claimed or granted. The rate of subdivision increased during the last two decades of the 19th century, with 1189.366 acres. Timber companies and land entrepreneurs began intensive speculation from 1901-1912, involving 80 percent of the tracts and 87.3 percent of the acreage $(10,340.65$ acres $)$ in the studied sample. The average size of these tracts increased through time, as timber companies and speculators "blocked up" large timber tracts. From 1868-1877, the average tract size was 154.75 acres, increasing to 237.373 acres in the late 19th century, and averaging 369.309 acres in the 1901-1912 period.

\section{The Piney Creek Watershed}

Twelve original land surveys in the Davy Crockett National Forest fall within the Piney Creek watershed. These are John George (1835), A. Andrada (1835), M. Marmon (1835), J. L. Boden (1835), James Henley heirs (1851), W. D. Redd (1854), Washington Jones (1859), A. Lowrey (1865), Wm. S. Kinnard (1868), H. Maness (1871), and W. S. Due (1871).

These tracts were plotted onto the 7.5' USGS topographic quadrangles that contain the Piney Creek watershed. Using the Direct Gradient Method (O'Brien 1984), which combines information on slope, aspect, drainage, and topographic gradient, it was possible to plot each witness tree $(n=73)$ within a specified physiographic zone. Four broad physiographic zones were identified in the study area: (1) river or streamside; (2) floodplain; (3) slope; and (4) upland. The floodplain was separated from the streamside zone because broad floodplains have a different ecology. The witness trees were relatively evenly distributed among the landforms, with 46.5 percent on slopes, 30.19 percent in the uplands, 13.7 percent in the streamside zone, and 9.7 percent in the floodplain (Figure 1).

\section{Forest Composition}

The slope was the most diverse zone, represented by seven species (Figure 2): dogwood, sweet gum, hickory, red oak, post oak, blackjack oak, and pine. Pine was the dominant species (52.9 percent), with an admixture of hickory (17.6 percent) and sweet gum ( 11.8 percent). Minor components included post oak (5.9 percent), blackjack oak (5.9 percent), red oak (3.9 percent), and dogwood (3.9 percent).

The streamside zone was the second most diverse, being represented by five species: ash, sweet gum, ironwood, red oak, and black oak (Figure 3). The dominant species was red 


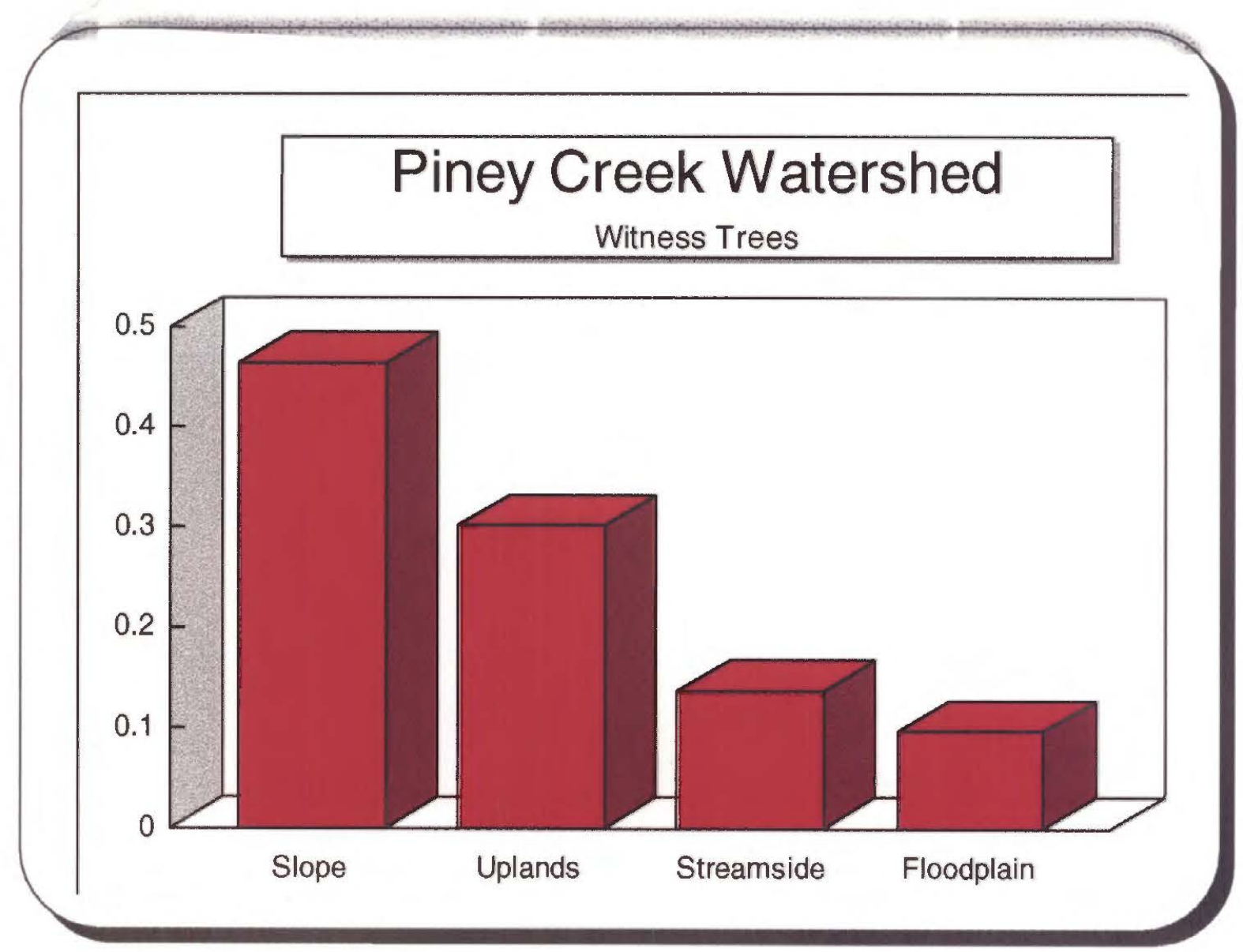

Figure 1. Witness trees with in the physiographic zones.

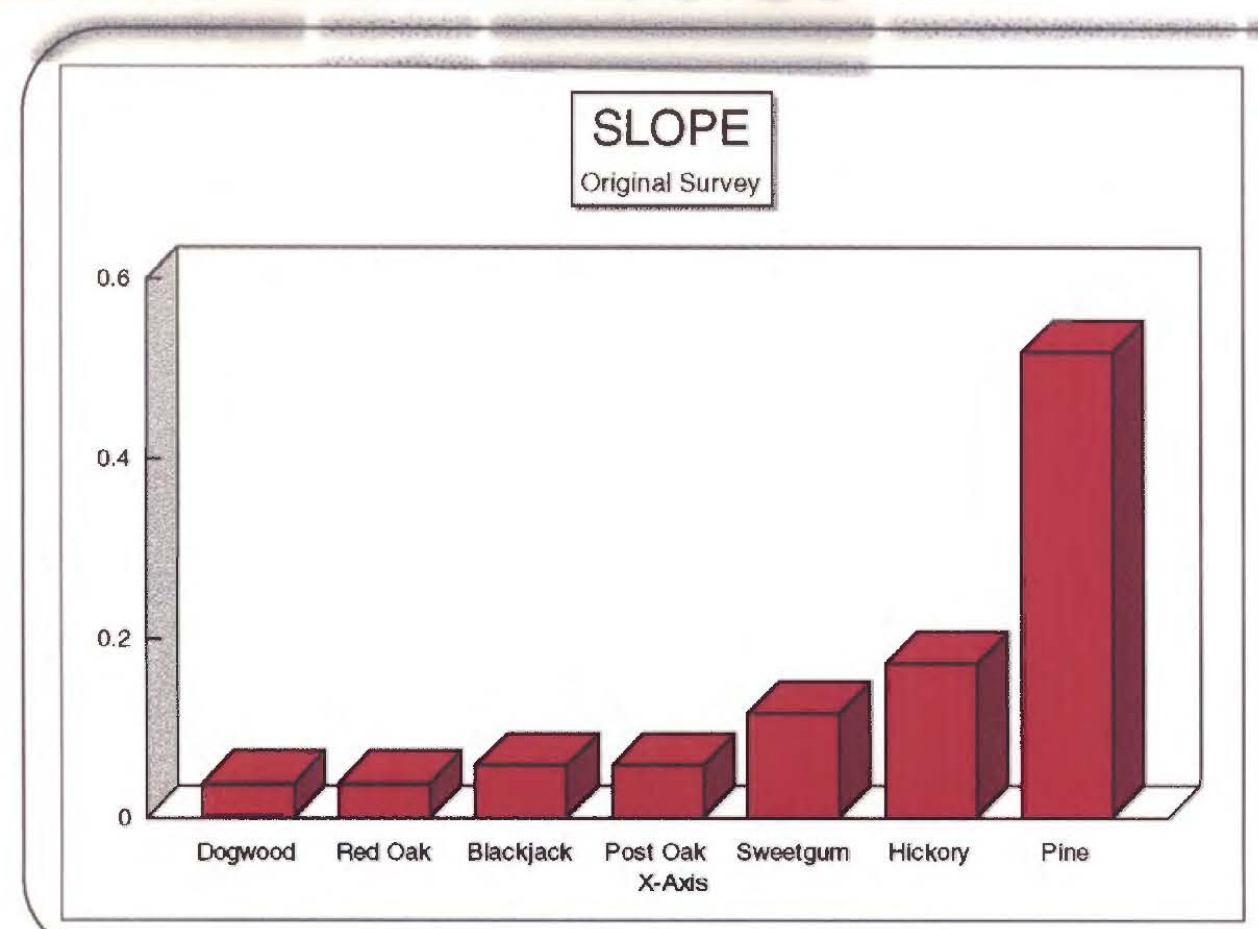

Figure 2. Trees in original survoy on slopes. 


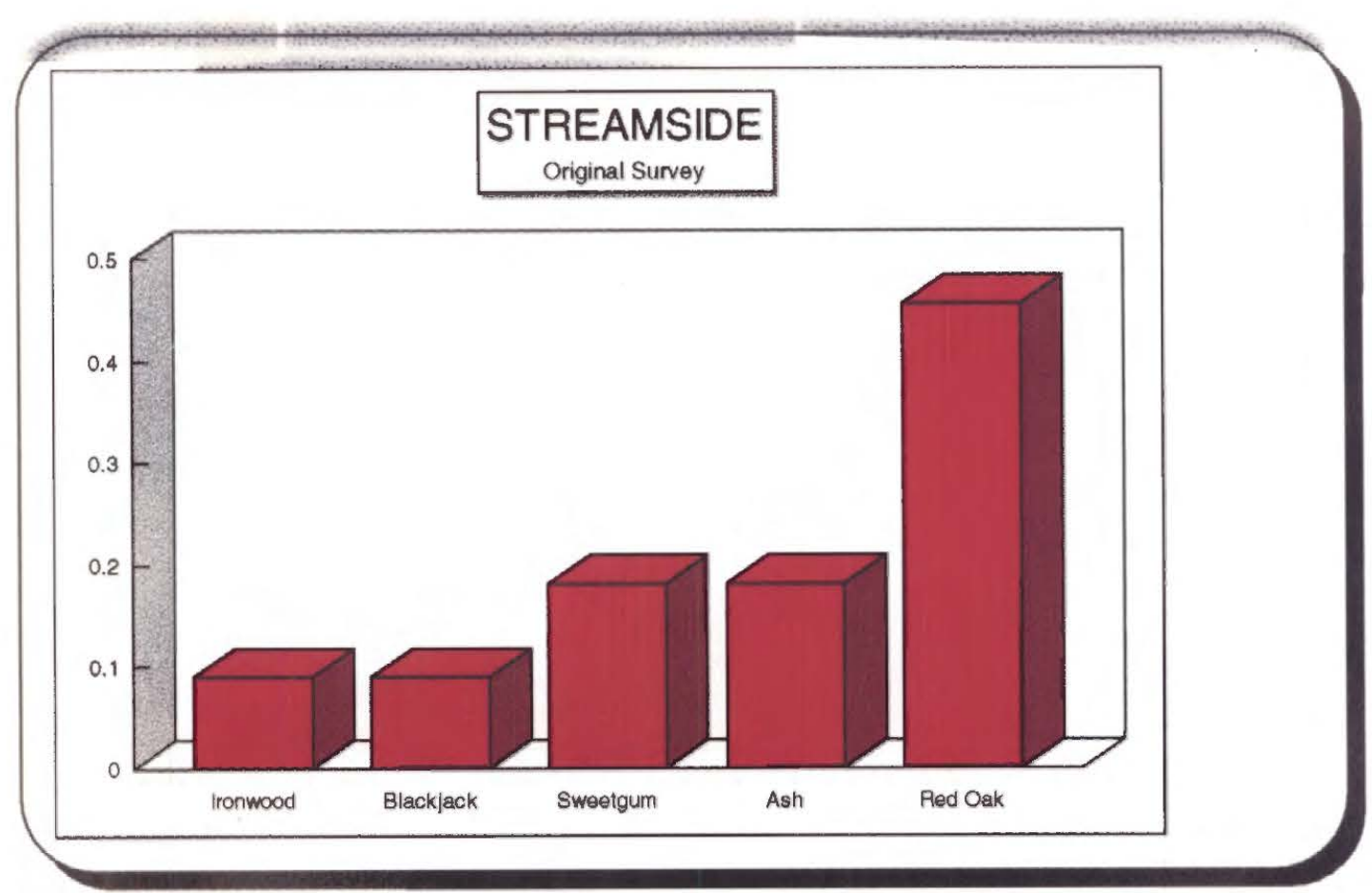

Figure 3. Trees in originat survey on streamside.

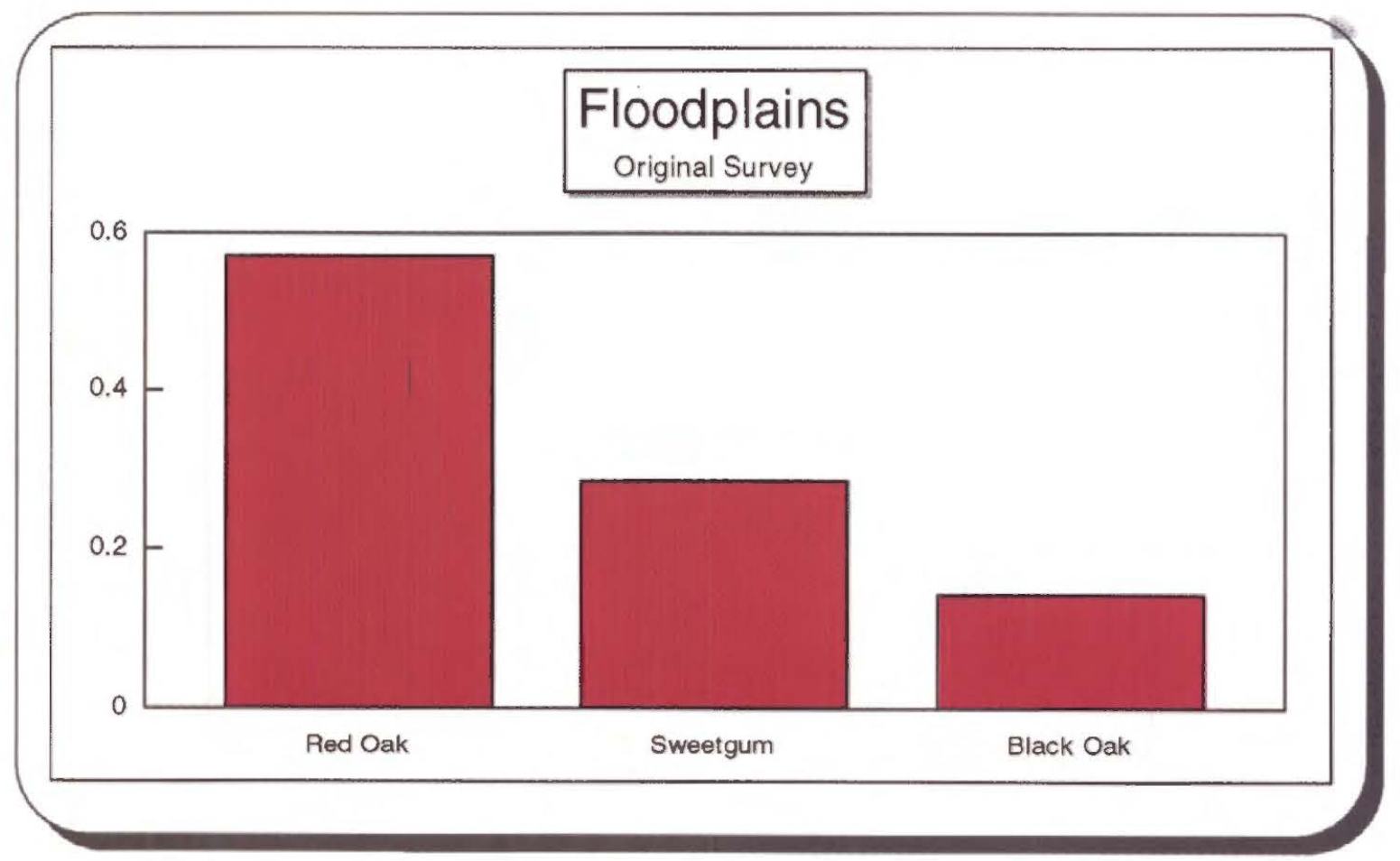

Figure 4. Trees in original survey located in floodplain. 
oak ( 50 percent), followed by ash ( 20 percent), and sweet gum ( 20 percent). Minor components included blackjack oak (5 percent) and ironwood (5 percent).

The floodplain had only three species: red oak, sweet gum, and black oak (Figure 4). Red oak was the dominant species (57.1 percent), followed by sweet gum ( 28.6 percent) and black oak ( 14.3 percent).

The uplands also contained only three species: pine, sweet gum, and blackjack oak (Figure 5). Pine was dominant, with 91 percent of the recorded species. Sweet gum and blackjack were minor components ( 4.5 percent each).

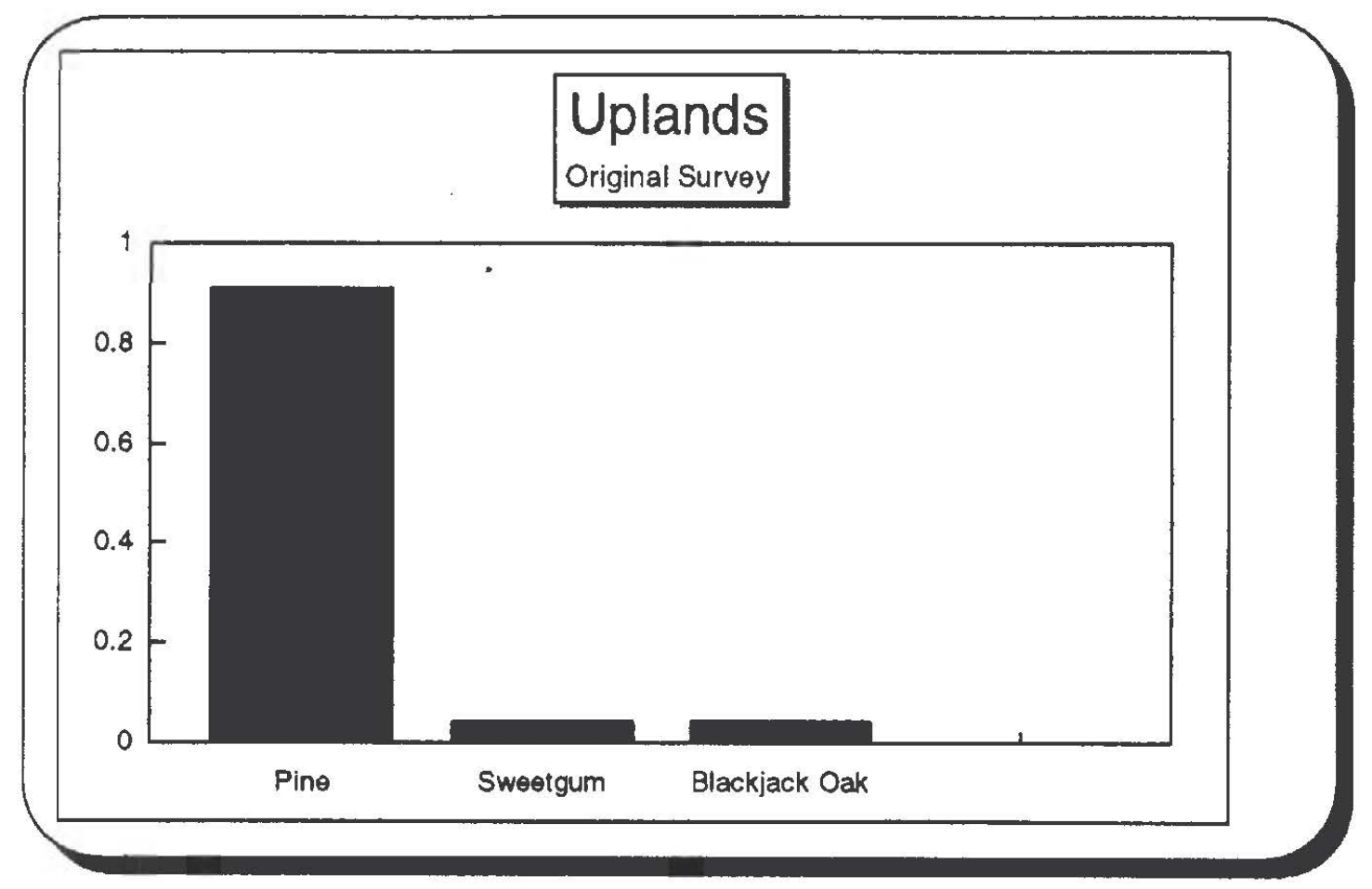

Figure 5. Trees in original survey on uplands.

\section{Forest Density}

Native prairies were not described in the field notes for Piney Creek, but were described elsewhere within the Davy Crockett National Forest. The criteria used was defined by Schafale and Harcombe (1983): areas with witness tree-to-corner distances greater than 20 varas may be called prairies. Only two corners ( 24 and 24 varas) fell in such areas within the Piney Creek watershed. These were observed in slope and upland pine communities, and may be indicative of the presence of fire in the ecosystem. These observations may also indicate those settings most conducive to native longleaf pine communities.

The upland zone was the most dispersed, with a mean witness tree distance of 8.93 varas (with a range of 1.2-25 varas). The mean diameter of pine was 13.8 inches, with a mean 
distribution of 4-30 inches. The mean diameter of sweet gum was 5 inches; blackjack oak diameters were not recorded.

In addition to being the most diverse zone, the slope was the densest with a mean witness tree distance of 5.56 varas. The mean diameter of pine was 2.8 inches, less than for the upland zone, with a distribution of 4-24 inches. Sweet gum in the slope zone had a greater mean diameter (13.5 inches), with a range of 8-18 inches. The red oak was 12 inches in diameter; post oak diameters were not recorded. Blackjack oak mean diameters were smaller ( 6.5 inches), followed by hickory (5.0 inches) and dogwood (4.0 inches).

the mean densities of the stream and floodplain witness trees fell between those of the slope and upland (7.05 and 7.24 varas, respectively. Red oaks along the stream were slightly larger (14.25 inches in mean diameter) than those on the slope, and the post oak diameters were not recorded. A black oak mean diameter of 8.0 inches was recorded for both streamside and floodplain zones. Sweet gum diameters were 8 inches for the streamside zone, and 10 inches for the floodplain.

\section{Discussion}

Based on the original GLO surveys, it is possible to quantify the original tree composition of the Piney Creek watershed. Broadly speaking, pines were restricted to slope and upland physiographic settings. Here there is evidence for some type of canopy disturbance, possibly fires, that promoted pine dominance. There were no observations of pine in the floodplain or along streams, suggesting that fire was not a part of the local ecology.

\section{Subdivisional Surveys}

Two subdivisional surveys of original GLO land grants were available for the study area: the T. B. Davis parcel (1907) in the A. Andrada survey, and the C. Ashworth parcel (1901) in the T. Wortham survey. Only floodplain, slope, and upland physiographic zones are represented in these parcels, and an additional species (burr oak) is recorded for the floodplain zone. The mean corner-to-witness tree distance is 5.4 varas, suggesting an increased density. The slope zone contained pine ( 66.6 percent) and dogwood. The mean density was 5.86 varas, similar to the original vegetation density of this zone.

The upland zone was still dominated by pine ( 75 percent), with the addition of black oak. The mean density was 6.2 varas, indicating a denser canopy than before. The mean pine diameter was 12.33 inches, less than the original forest.

\section{Timber Company Inventories}

In 1930, two original surveys in the Piney Creek watershed were inventoried by timber companies: the J. Henley survey (1707 acres) and the W. D. Redd survey (1429 acres). The number of trees, diameter, and length were calculated for each survey.

The J. Henley survey was characterized as 1420 acres of pine and 287 acres of "field" with "fair reforestation." It was dominated by shortleaf pine ( 93.2 percent), with an estimated 17,260 trees between $10-15$ inches in diameter, and 925 trees between 16-24 inches. The hardwood component consisted of several species, dominated by red gum $(n=500)$, red oak $(n=440)$, black gum $(n=230)$, post oak $(n=60)$, hickory $(n=60)$, overcup oak $(n=20)$, and elm $(n=19)$. The W. D. Redd survey had 1129 acres of pine, 200 acres of swamp, and 
100 acres mixed with "good reforestation." This survey was also dominated by shortleaf pine (89.6 percent), with an estimated 16,300 trees between 10-16 inches in diameter, and 1362 trees between 16-24 inches. The hardwood component consisted of 1540 red oak, 331 red gum, 138 black gum, and 50 overcup oak.

\section{Discussion}

Compared to the original GLO data, the 1930 tract surveys indicate a 40 percent increase in the dominance of pine. Post oak and black oaks are essentially removed from the forest, and hickories are greatly reduced. The importance of red oaks and gums was reduced in the floodplains where pines were now established. However, the condition of the forest referenced from the historic surveys may not be representative of the natural landscape, as it was most likely influenced by the Native Americans, but these surveys do indicate the vegetation conditions that existed when the Anglo-American settlement of the landscape began. With our continued existence and persistence in managing the forests to provide products for us, it is obvious that we have altered what was first encountered.

\section{References Cited}

Bowles, F. G.

1966 A History of Trinity County. Groveton Independent School, Groveton, Texas.

Bridges, E. L.

1989 Longleaf Pine Communities of the West Gulf Coastal Plain. Natural Areas Journal 9(4):246-263.

Butzer, K. W.

1964 Environment and Archeology: An Introduction to Pleistocene Geography. Aldine Publishing Company, Chicago.

Flanagan, R.

1992 The Pristine Myth: Some Scholars Contend Europeans Found Landscapes Already Transformed by Indians. The Oregonian.

Forney, S. J.

1993 Heritage Resources: Tools for Ecosystem Management. Paper presented at the 26th Annual Meeting of the Society for Historical Archaeology, Atlanta.

Jurney, D. H.

1988a Early Historic Vegetation Zones. In Historic Farming on the Hogwallow Prairies: Ethno-Archaeological Investigations of the Mountain Creek Area, North Central Texas, compiled by D. H. Jurney, S. Lebo, and M. M. Green, pp. 333-351. Joe Pool Lake Archaeological Project, Vol. II. Archaeology Research Program, Institute for the Study of Earth and Man, Southern Methodist University, Dallas.

1988b Early Vegetation Recorded in the General Land Office Surveys. The Record 42(3):170-176. Dallas Archeological Society, Dallas.

Jurney, D. H. and R. W. Moir (editors)

1987 Historic Buildings, Material Culture, and People of the Prairie Margin: Architecture, Artifacts, and Synthesis of Historic Archaeology. Richland Creek Technical Series, Vol. V. Archaeology Research Program, Institute for the Study of Earth and Man, Southern Methodist University, Dallas. 
Loughridge, L. H.

1884 GeneralDescription of the State of Texas: Report on the Cotton Production of the State of Texas. U.S. Department of the Interior, Washington, D.C.

Noss, R. F.

1985 On Characterizing Presettlement Vegetation. Natural Areas Journal 5(1):5-19.

O'Brien, M. J.

1984 Grassland, Forest and Historical Settlement: An Analysis of Dynamics in Northeast Missouri. University of Nebraska Press, Lincoln.

Peterson, J. (editor)

1994 Voices in the Forest: An Interview with Bob Zybach. Evergreen Magazine (March/April), pp. 7-25.

Schafale, M. P. and P. A. Harcombe

1982 Presettlement Vegetation of Hardin County, Texas. American Midland Naturalist 109(2):355-366.

Urlich, B. B.

1984 Crockett Newspapers 1853-1896. Crockett Publishing Company, Crockett, Texas. 